\title{
An investigation of occupational accidents and safety risks in policing: Views of employees
}

\author{
Murat Gözübenli ${ }^{1}$ \\ Fatih Mehmet Harmanci ${ }^{2}$
}

\begin{abstract}
Policing is one of the riskiest and dangerous professions by its nature. Police officers face a range of risks at work: homicide, assaults, attacks, communicable diseases, car crashes or explosions. The risks vary according to the task being undertaken such as arresting offenders, attending street disturbances or performing traffic duties. These risks, having the characteristics of occupational accident in a way, have institutional losses like compensation, loss of manpower and reputation besides individual results like injury, death, mutilation, and posttraumatic stress disorder, exposure to psychological disorders or decrease in quality of life. Opinions and suggestions of 1066 employees currently working at different ranks and units in Turkish National Police in regards with reducing the risks of occupational accidents and safety risks were studied in this research. Suggestions of the participants were reviewed under total nine headings (themes) consisting of training, physical fitness and health, security measures, institutional policies and procedures, managerial policies, working conditions, equipment, uniforms, and patrol cars.
\end{abstract}

Keywords: Occupational accident, work safety, police, risk, injury, death, Turkish National Police

\section{Introduction}

Occupational accidents are one of the most important problems of the work life in Turkey, as well as other parts of the world. Occupational accidents in Turkey occur pretty much compared to developed countries (Camkurt, 2013). 70-80 thousands of occupational accidents occur every year, and their cost only to social security system is 4 billion TL according to the records of Social Security Institution (Yilmaz, 2013).

Occupational accident is described as, "an unexpected and unplanned occurrence which results in a certain damage or injury" (ILO, 1983). In Occupational Health and Safety Law (article 3), it was described as, "any occurrence taking place at the workplace or due to the performance of work which leads to death or physical or mental impairment to the physical integrity of the victim". Generally accepted description of the occupational accident in the discipline is "an occurrence which physically or mentally injures due to the performance of work or the nature of work that happen suddenly and by an outer effect while being under the authority of the employer" (Güzel, Okur \& Caniklioğlu,

\footnotetext{
${ }_{1}^{1}$ Ph.D., Turkish National Police, muratgozubenli@yahoo.com

${ }^{2}$ Ph.D., Turkish National Police, fatihharmanci@,hotmail.com
} 
Gözübenli, M., \& Harmanc1, F. M. (2016). An investigation of occupational accidents and safety risks in policing: Views of employees. International Journal of Human Sciences, 13(1), 809-829. doi:10.14687/ijhs.v13i1.3446

2012, p. 394). Bostanc1 (2005) indicated that there were 3 basic factors of occupational accidents in the doctrine which are a) coming out, b) suddenly occurring, and c) unexpected incident. According to Bostanc1, the accident occurring due to the fault of the employee is also deemed occupational accident.

Many occupational accidents occur since institutions and organizations do not take necessary measures for occupational health and safety adequately, employees do not obey necessary safety rules, and related public bodies do not fulfil their inspection/audit tasks properly in developing countries like us (Türen \& Gökmen, 2014). Research on which factors cause occupational accidents have shown that $20 \%$ of them occur due to personal and $80 \%$ of them occur due to physical, mechanical and environmental conditions (Çam, 1991). These data show the significance of the measures for occupational health and safety. Researches also show that occupational accidents can be reduced if states and institutions take measures in respect to increasing occupational health and safety like preparing stricter procedures, fulfilling more efficient audit, improving working conditions, training the staff and raising awareness in them, replacing the worn equipment (Camkurt, 2007). Uncalled-for injury of employees reduces as well as loss of manpower decreases to minimum and thus, institutional efficiency also increases through the measures taken for occupational health and safety (Camkurt, 2007).

Police officers are among the riskiest groups to lose their life or get injured (Brown \& Langan, 2001; Prenzler, 2006) since they perform always risky and hazardous tasks (Driscoll et al.., 1999; Hackitt et al., 2009; Prenzler, 2006). Police officers generally deal with criminals and problematic people (the mentally ill, extremely stressed, terrorist, drunk, stoned, psycho etc.) in the society, and have to respond with dangerous incidents (suspicious package, fire, narcotics/terror operations, fight, domestic violence incidents etc.). Police officers face a range of risks at work: homicide, assaults, communicable diseases, injuries during car crashes and regular abuse. The risks vary according to the task being undertaken (for example, whether performing traffic duties, attending street disturbances, arresting offenders, or transporting offenders to court).

Existing research have revealed that most of police injuries are the results of caused by accidents (Brandl \& Stroshine, 2012; Kaminski, 2007). For example, Brandl ve Stroshine (2012), who studied 4,979 injury cases occurred in a police department between 2006-2008, found that almost half of them (48.7\%) happened due to accident (traffic accident, falling down from height, slipping etc.), $41.7 \%$ during resisting of the person who police officers try to catch/detain, and $9.7 \%$ by physical assaults. Kaminski (2007), who studied injuries of police officers who chase on foot in another police department, found out that among 187 injuries, 57\% happened due to accidents such as falling from height, slipping, and 33\% by assault. In terms of police deaths, the statistics revealed mixed results, based on the type of country. For example, a study in the U.S., investigated that causes of deaths of 126 police officers in 2014, found that half of these deaths (50\%) happened due to armed assault, 38\% due to traffic accident, remaining $12 \%$ due to diseases due to profession (heart attack etc.)(NLEOMF, 2015). On the other hand, in a study in Australia, where rate of using guns is less, it was established that $75 \%$ of death of police officers happened due to pure accident (traffic accident, falling, shooting himself etc.), and $25 \%$ by assault (Allard \& Prenzler, 2009).

Occupational accidents in the policing profession cause many individual, institutional and societal negative effects. Occupational accidents also have effects like experiencing posttraumatic stress disorder, psychological disorders, reduction in efficiency, decrease the quality of life, feeling of inadequacy as well as direct effects like death, injury and becoming permanently disabled (Savery, Soutar \& Weaver, 1993; Shucard et al., 2012). In respect to institutional aspect, situations like loss of manpower, damaged equipment and paying for compensation followed by occupational accidents cause loss of institutional prestige besides economical loss of police 
Gözübenli, M., \& Harmanc1, F. M. (2016). An investigation of occupational accidents and safety risks in policing: Views of employees. International Journal of Human Sciences, 13(1), 809-829. doi:10.14687/ijhs.v13i1.3446

departments (Mayhew, 2001). Getting injured or killed of a policeman during duty negatively affect not only himself but also his colleagues, family and society.

Although effects of occupational accidents in policing are enormous, there are not enough studies on this topic. Some studies have revealed that police officers get injured or lost their lives generally due to the personal reasons (Hackitt et al., 2009; Pinizzoto, Davis \& Miller, 2002). Mayhew (2001), who studied death of police officers, found out that they mostly lose their lives when they did not take necessary measures while intervening with people who were psycho, drunk or drugged and did not obey the procedures like too much negotiating with such people or not waiting for back-up. Pinizzoto et al. (2001), who studied the reasons of traffic accidents, on the other hand, found out that factors like carelessness of staff, not caring rules, lack of experience and training came to the fore.

Although it is impossible to prevent injuries and deaths in the profession of policing, it is alleged that safety related risks could be reduced through some individual and institutional level precautions (Pinizzoto et al., 2002). Although there are some studies on injuries and deaths of police officers, there exists no specific holistic research on this issue. The purpose of this study is to investigate the measures that can be taken to prevent occupational accidents and reduce safety related risks in the policing based on the views of employees. When considered that police officers either personally make or witness an occupational accident at least once in their lives (Pinizzoto, Davis \& Miller, 2002), it is quite important to take their views on this topic. For this purpose, views and recommendations of the staff currently working at different ranks and units in Turkish National Police were investigated in this study.

\section{Method}

This research is a descriptive study in the nature of an assessment to determine the opinions of the personnel of Turkish National Police (TNP) to prevent occupational accidents occurring in the profession of policing. Qualitative research method was used to obtain the views of employees currently working at different ranks and units in TNP and to analyse these views in a holistic way. A web-based questionnaire was applied via POLNET, which is in-service intranet web of TNP, in 2013. In the questionnaire, after the participants were asked to indicate their demographic characteristics (rank of duty, city and branch where they serve, education status and period of service), they were asked to reply an open-ended question like, "What can be done to prevent occupational accidents and reduce safety related risks in the profession of policing?" freely. Purpose of such an open-end question is to obtain more extensive and detailed information about the topic.

1066 persons responded the questionnaire, which stayed on POLNET for 20 days. The sample size because 356 persons required for 95\% confidence level in 260.000 population as indicated in "Theoretic Sample Size Chart" by Balc1 (Balc1, 2007, s. 107). Answers given by the participants were analysed in respect to contents by taking the relevant literature into account. In content analysis, data are first divided into categories, and then these categories are turned into themes (groups) so that they can be classified according to certain criteria (Yıldırım \& Şimşek, 2006, p. 18-19). Descriptive approach was used for the analysis of the data in the groups as Wolcott (1994) suggested. Views and suggestions of the participants to prevent occupational accidents in policing were presented in themes, categories and focal points. How many times the participants indicated focal points were shown by indicating their frequencies nearby. Furthermore, some of the views and suggestions of participants were shared.

\section{Results}

Views of the police employees in regard to preventing occupational accidents and reducing the risks of safety in policing were studied in this research. 1066 police employees participated in 
the research. In this chapter, first, demographical features of the participants, then their views will be presented.

\subsection{Demographics}

Demographical features of the participants were evaluated under total seven headings consisting of their gender, age, level of education, periods of service, rank, unit, and province.

Table 1. Demographics of Participants

\begin{tabular}{|c|c|c|}
\hline Variable & $\mathrm{n}$ & $\%$ \\
\hline \multicolumn{3}{|l|}{ Gender } \\
\hline Male & 1038 & 97,4 \\
\hline Female & 28 & 2,6 \\
\hline \multicolumn{3}{|l|}{ Age } \\
\hline $20-30$ & 234 & 21,9 \\
\hline $31-40$ & 445 & 41,7 \\
\hline Over 41 & 387 & 36,3 \\
\hline \multicolumn{3}{|l|}{ Level of Education } \\
\hline Doctorate & 4 & 0,4 \\
\hline Post Graduate & 58 & 5,4 \\
\hline Bachelor's Degree & 478 & 44,8 \\
\hline Two-year Degree & 472 & 44,3 \\
\hline High School & 54 & 5,1 \\
\hline \multicolumn{3}{|l|}{ Period of Service } \\
\hline $1-5$ & 155 & 14,5 \\
\hline $6-10$ & 204 & 19,1 \\
\hline $11-15$ & 179 & 16,7 \\
\hline $16-20$ & 367 & 34,4 \\
\hline Over 21 & 161 & 15,1 \\
\hline \multicolumn{3}{|l|}{ Rank } \\
\hline Police Officer & 875 & 82 \\
\hline Immediate Supervisor & 149 & 13,9 \\
\hline (Chiefpolice officer, deputy inspector inspector, chief inspector) & & \\
\hline $\begin{array}{l}\text { Middle Manager } \\
\text { (superintendent, 4th degree superintendent, } 3 \text { th degree superintendent) }\end{array}$ & 34 & 3,1 \\
\hline $\begin{array}{l}\text { High Level Manager } \\
\text { (2th degree superintendent, 1th degree superintendent) }\end{array}$ & 8 & 0,7 \\
\hline \multicolumn{3}{|l|}{ Unit } \\
\hline Operational & 758 & 71,1 \\
\hline Managerial & 308 & 28,9 \\
\hline \multicolumn{3}{|l|}{ Province } \\
\hline Western Provinces & 813 & 76,2 \\
\hline Eastern Provinces & 130 & 12,1 \\
\hline Central Branches & 117 & 10,9 \\
\hline Total & 1066 & 100 \\
\hline
\end{tabular}


As shown in Table 1, the majority of the participants were male $(97,4 \%)$ and $2,6 \%$ were female. The average age was 37,6 . The majority of the participants $(94,9 \%)$ had two-year degree or bachelor's degree. The average year of service was 14,5 . The majority of the participants $(82 \%)$ were police officers. The majority of the participants worked in operational units $(\% 71,1)$, such as public order, traffic and police stations. More than $2 / 3$ of the participants served in western provinces and nearly $1 / 10$ of the participants from Istanbul.

In addition, participants were asked to answer the following question "Have you ever been subjected to any occupational accidents (falling, assault, accident etc.) previously? If so could you name them?". $34 \%(n=345)$ of the participants stated that they previously had occupational accident, $26 \%$ did not have any, and $40 \%$ did not reply this question. Some of the participants had experienced more than one occupational accident. Types of these accidents are shown in the table below.

Table 2. Occupational Accidents Experienced by Participants

\begin{tabular}{lc}
\hline Type of Occupational Accident & $\mathbf{n}$ \\
\hline Physical resistance & 107 \\
Assault/attack & 105 \\
Physical assault (battering, pushing etc.) & 54 \\
Armed or bombed attack & 23 \\
Knife attack & 11 \\
Attack with stone & 9 \\
Attack with stick & 4 \\
Attack with Molotov cocktail & 4 \\
Attack with blade & 1 \\
Biting & 1 \\
Lynching & 1 \\
Traffic accident & 103 \\
Falling & 21 \\
Unintentional discharging firearm & 4 \\
Electric shock & 2 \\
Fire/explosion & 2 \\
Dog biting & 1 \\
Total & 345 \\
\hline
\end{tabular}

It is shown in Figure 8 that the participants mostly experienced resistance $(n=107)$, assault $(n=105)$, and traffic accident $(n=103)$. Almost half of the personnel who were assaulted physically (pushing, punching, tripping up etc.), the remaining pointed out that they were attacked by gun, knife, blade, stone etc. On the other hand, 21 of the participants were injured due to falling and the remaining nine due to gun burst, electric shock, fire/explosion and dog biting.

\subsection{Views of Participants on Occupational Accidents and Safety Risks}

Participants were asked to answer the following question? "What dou you think of occupational accidents and safety risks in policing and what measures should be taken to prevent them?". According to the participants, policing is an extremely dangerous work and police officers work under considerably very risky conditions. Based on the answers of the participants, police officers may face occupational accidents and safety risks at work, in which they get injured, disabled or lose their life. The most stated risks are the followings:

- Physical resistance by suspects

- Attack (physical or with knife, stone, stick, etc.) by suspects/bystanders 
Gözübenli, M., \& Harmanc1, F. M. (2016). An investigation of occupational accidents and safety risks in policing: Views of employees. International Journal of Human Sciences, 13(1), 809-829. doi:10.14687/ijhs.v13i1.3446

- Shooting by suspects

- Armed or bombed attack by terrorists

- Involving in a traffic accident

- Hitting by a vehicle during traffic controls

- Falling down while chasing a suspect

- Discharging own firearm unintentionally

- Losing health (having stress, fatigue, hypertension, hearth attack, etc.)

- Getting a communicable disease from a suspect or crime scene

Based on the answers of the participants, the risks at police work vary according to the task being undertaken. The riskiest police tasks are: performing traffic duties, chasing fleeing suspects, attending street disturbances/fights/domestic violence calls, or arresting/searching/transporting offenders. In order to reduce occupational accidents and safety risks, participants offered many suggestions. These suggestions were reviewed under nine themes consisting of training, physical fitness and health, security measures, institutional policies and procedures, managerial policies, working conditions, equipment, uniforms, and patrol cars. Suggestions in these themes were shown as focal points in tables. Furthermore, some significant and attention-grabbing views and suggestions were presented by a descriptive approach by quoting directly from the answers of the participants.

\section{Table 3. Suggestions on Training}

\begin{tabular}{lc}
\hline Focal Points & $\mathbf{n}$ \\
\hline Giving training on occupational accidents and work safety & 479 \\
Arranging specifically trainings and in-service courses & 369 \\
Guns and shooting techniques & 85 \\
Physical defence & 79 \\
Protection of crime scene & 59 \\
Intervening with mentally ill persons & 53 \\
Fire and explosions & 36 \\
Techniques of advance driving techniques & 32 \\
Techniques of first aid & 25
\end{tabular}

Increasing the effectiveness of trainings and courses (providing them by experts, real-life 123 scenarios, etc.)

Total

It shown in Table nine that almost all of the participants $(n=973)$ had suggestions about training. Almost half of the participants $(n=479)$ suggested that training about occupational accidents and occupational safety should be given to all the personnel. It was understood that some of the participants remarked that most of the personnel did not have enough knowledge about occupational health and thus, informative and awareness increasing trainings were very important.

369 participants had suggested that specific trainings (firearm using and shooting techniques, physical defence, protection of crime scene, intervening with mentally ill persons, fighting with fire, vehicle using techniques) should be given to police officers. It is understood that the most mentioned in-service training $(n=85)$ is about gun using and shooting techniques. Expressions of a participant who emphasized lack of training was inadequate are as follows:

Our police officers use gun where they should not, and they do not use gun where they should. Therefore, they shoot citizens in vain, or they are shot by citizens. Situations where gun should be used must be completely taught. Necessary trainings to decide promptly to leave no room for doubt in case of an incident.

123 participants offered to increase the effectiveness of trainings and courses. For example, according to many of these participants, these trainings should be given by experts who have 
Gözübenli, M., \& Harmanc1, F. M. (2016). An investigation of occupational accidents and safety risks in policing: Views of employees. International Journal of Human Sciences, 13(1), 809-829. doi:10.14687/ijhs.v13i1.3446

both theory and practice. In addition, some participants pointed out the important of scenariobased learning. Suggestion of one of the participants is as follows:

Applied trainings should be carried out through simulators and computer in line with scenarios adapted from real life. Police officers can use the most convenient technique and way of action in different situations only by such trainings.

Table 4. Suggestions on Security Measures

Focal Points $\mathbf{n}$

Taking all necessary precautions in all incidents 180

Searching/handcuffing the suspects

Professional intervening with sensitive situations like suspicious package etc.

Avoiding intervening incidents with insufficient equipment

Obeying traffic rules

Being careful on safety rules with firearms

It shown in Table 11 that almost half of the participants $(n=523)$ brought about the importance of obeying safety rules. The most important of these rules is $(n=180)$ taking all necessary precautions in all incidents. Many participants expressed that police officers acted unguardedly and they should not think such "This does not happen to me", "This person does not harm me" or "This is a simple incident. Why should I need such precaution?" and they should prepare themselves always for the worst scenarios.

171 participants suggested that suspects of serious crimes should be absolutely searched and the one who are detained and handcuffed. A participant explained the importance of being cautious on this matter as follows.

It is important to learn and confirm the identification information of the suspicious persons; however, life safety is more important than that. It should be taken into account that the criminal could have an object like a second gun or a knife. Furthermore, suspects who behave aggressively resist or drunk/stoned should be absolutely handcuffed so that they cannot harm or shoot us by taking our guns.

120 participants indicated that police should not respond the incidents with insufficient equipment (bullet-proof vest, helmet, protective armour etc.). One of the participants expressed the drawback about this issue by telling an incident he experienced:

I was assigned among Fener fans without helmet and shield in Fener-Trabzon match in Trabzon. I was injured at my chest because of a big stone since fans of Trabzon threw stones heavily.

112 participants suggested that responding should be done professionally in cases like suspicious packages. The suspicious items should be examined by specially trained staff. First responders should avoid unconscious intervenes and prevent unrelated personnel and citizens from entering the crime scene. Opinions of one of the participants about this matter are as follows:

Suspicious packages are not toys. Let everybody practise their field of specialization. Otherwise, unexpected disasters can happen. Therefore, neither us, nor citizens should access the crime scene until required safety measures are taken, safety line is set and crime scene investigation team arrives.

71 participants emphasized on traffic rules and stated that the personnel should absolutely obey traffic rules. Criticism of a participant in this issue as follows:

Our colleagues do not obey traffic rules by acting by considering the situation of being police officers, they rush to respond the calls, but they generally pass red lights. Thus, they cause accidents. In addition, the fact that they do not use safety belt increases the risk of getting injured. 
Few participants $(n=11)$, emphasized obeying the safety rules about firearms. One of the participants elaborated this issue as follows:

Our firearms should be kept in their case and always locked when not used. Cases should be easy for us but difficult for others to open. Guns should always be checked when loading and unloading and cleaning to see whether they are loaded or not. Guns should never be pointed at anybody. They should be kept away from the reach of children after duty.

Table 5. Suggestions on Equipment

\begin{tabular}{lc}
\hline Focal Points & n \\
\hline Tear gas & 404 \\
Light steel vest & 360 \\
Electroshock weapon & 152 \\
Hand lamp & 150 \\
Wireless & 135 \\
Open-close baton & 90 \\
Plastic bullet & 77 \\
Camera & 53 \\
Gloves & 50 \\
Portable road blocker & 44 \\
Plastic handcuffs & 28 \\
Wireless handset earphone & 8 \\
\hline
\end{tabular}

The participants suggest that a lot of equipment that the police need should be given to them completely and in good condition. Mostly tear gas $(n=404)$ and light steel vest $(n=360)$ and then electroshock weapon device $(n=152)$ and hand lamp $(n=150)$ were emphasized in respect to equipment. Some of the participants expressed the lack of equipment together with experiences they had. One of the participants shared the following about tear gas:

I got slightly injured while I was counteracting with the thief since he was very strong. I could have been injured more heavily if not my colleague's belp. It would have been much easier if I had tear gas with me.

Sharing of a participant about steel vest is as follows:

We stand guard in $15 \mathrm{~kg}$ steel vest. It is both too heavy and restricts our ability to move. They should be replaced with light and modern steel vest.

Opinions of a participant about electroshock device which is not yet used in our country are as follows:

I think that if the police intervene with a person by counteracting from 5-6 meters distance without physical touch with electroshock device would prevent an attack against the police and prevent them from injury.

Sharing of a participant about hand lamp is as follows:

Battery of my hand land went dead since it was cheap while I was chasing a thief and I was tripped by wire and I got injured. This would not have occurred if our state would have given me a more quality band lamp." 
Gözübenli, M., \& Harmanc1, F. M. (2016). An investigation of occupational accidents and safety risks in policing: Views of employees. International Journal of Human Sciences, 13(1), 809-829. doi:10.14687/ijhs.v13i1.3446

Table 6. Working Conditions

Focal Points

$\mathbf{n}$

Reducing work overtime and additional tasks

Providing the personnel sufficient resting opportunity

Shortening the periods of guard duty and patrol car using

Benefiting from technology

It is shown in Table 6 that almost $2 / 3$ of the participants $(n=721)$ suggest to improve working conditions. Almost half of the participants $(n=511)$ pointed out that work overtime and additional tasks should be reduced in respect to this theme. Opinions of participant about work overtime are as follows:

The most important reason why police officers make mistakes and accidents is work overtime. Work overtime causes psychological and physically destruction of police officers. Work hours and time of duty of the

police should be arranged so that they can come to the work as rested. Time of work in this scope should not exceed 40 bours in normal times.

Some participants $(n=108)$ indicated that if the personnel are given enough time to rest they would be more careful and make less mistakes. For example, criticism of a participant about standing guard with long barrelled weapon at police stations is remarkable:

Personnel who stand guard are not allowed to rest once their task ends and they are assigned to complete other judicial and managerial tasks. This causes the personnel who comes for standing guard to fulfil their task exhausted and distracted.

Some participants $(n=48)$, on the other hand, pointed out that time of periods of guard duty and using patrol car should be shortened. Opinions and complaints of one of the participants about driving patrol car as follows:

We are obliged to use car more than 11-12 hours in one working day. Furthermore, the probability of making accident due to tiredness because of working long bours and sleeplessness especially, for drivers working in the night group.

Another suggestion of the participants $(n=14)$ is about benefiting from technology instead of physical strength. View of a participant is as follows:

Leaving the watch with weapon in low-risk spots and developing the camera system and fulfilling the watch task like that would ensure the personnel to be stronger and efficient.

Table 7. Suggestions on Institutional Policies and Procedures

\section{Focal Points}

Making arrangements on policies and procedures

Not opening unnecessary investigation against personnel e who use guns or force

Giving importance on vocational specialisation

Supporting the staff who has undergo an occupational accident

It is shown in Table 7 that 323 participants had suggestions on institutional policies and procedures. Half of these participants $(n=164)$ acknowledged that police officer generally hesitate 
Gözübenli, M., \& Harmanc1, F. M. (2016). An investigation of occupational accidents and safety risks in policing: Views of employees. International Journal of Human Sciences, 13(1), 809-829. doi:10.14687/ijhs.v13i1.3446

to use their guns due to the deficiencies in policies and procedures; therefore, necessary arrangements should be made. Criticism and suggestions of a participant in the issue are as follows:

No need to carry gun, it does not work anyway. If police officers shoot, they make all kinds of excuses. If police officers are shot there is no problem, it is shown normal. All the stages that our police officers should pass to overcome this situation should be arranged in a single procedure, and method of respond should be set according to the risk level to be determined, and all the applications should be carried out in accordance with this procedure.

It is understood that another suggestion of the participants $(n=96)$ on institutional policies is not to open managerial and judicial investigation against the personnel who shoot and use force. Opinions of a participant are as follows:

I see the risk of being subject to judicial investigation which causes the loss of self-confidence and fear of performing the duty, apart from physical hazards, the biggest potential danger. Because, using force during catching and detaining even within the legal frame, is being subject to investigation, and elaborative investigations cause the personnel to act reluctantly and diffidently to use necessary force during catching and detaining.

Some participants $(n=42)$ emphasized on vocational specialisation and branching. Criticism and suggestions of a participant about this issue are as follows:

Location of the staff change too often. And this causes the personnel to make mistake and get injured until they are accustomed to the new unit they are assigned. Therefore, every officer should not be assigned for any duty, but relevant officer should be assigned to the duty, especially location of the personnel who work in the units that require specialisation should not be changed for a long time and their specialisation should be increased through training.

It is remarkable that some participants $(n=21)$, even less in number; suggest that the staff who use force or have accident should be given legal support. Opinions of a participant about this issue are as follows:

Since most of our colleagues think that they cannot get legal aid, they fear to use even conditions are convenient and go through a bad patch. Our organization should materially and spiritually support the personnel who use gun or undergo an occupational accident, and supply them with a lanyer.

Table 8. Managerial Applications

\begin{tabular}{lc}
\hline Focal Points & $\mathbf{n}$ \\
\hline Do not putting subordinates in risky incidents & 120 \\
Not assigning subordinates such tasks requiring specialisation and not endangering & 19 \\
them & 10 \\
Checking the psychological status of the subordinates & $\mathbf{1 4 9}$ \\
Total &
\end{tabular}

It is shown in Table 8 that 149 participants reported suggestions on managerial applications. The majority of these participants $(n=120)$ suggested that police managers should closely monitor and led their subordinates in critical incidents. Opinions of a participant who complains about managers are as follows:

Some of our supervisors put us in a dangerous position by instructing us from distance without arriving the crime scene. It yields bad results. Therefore, they should be with us, especially, in critical and stressful incidents which the psycho and drunk etc. are involved in and they should not leave us alone. 
Gözübenli, M., \& Harmanc1, F. M. (2016). An investigation of occupational accidents and safety risks in policing: Views of employees. International Journal of Human Sciences, 13(1), 809-829. doi:10.14687/ijhs.v13i1.3446

19 participants suggested that managers should not assign their subordinates that tasks that require expertise. Opinions and complaints of participant are as follows:

Although we do not have neither uniforms, equipment nor training to fight with fire, our chiefs send us to crime scene in fire calls and they sometimes expect us to intervene before fire brigadier arrives. However, our duty is not to fight with fire, but provide security for life and property."

10 participants emphasized that managers should check the psychological status of the personnel. Opinions and suggestions of a participant about this matter are as follows:

Most of the personnel who underwent occupational accident have bad psychology. Therefore, chiefs should ensure necessary treatment for the personnel by learning about the bad psychology of the personnel before the incident. Psychological test should be applied on police officers who especially, work in social events at certain intervals (monthly, annually), and deficiencies should be completed through training and rehabilitation, and the stress police officers subject to should be minimized before it increases and becomes a sickness (material, spiritual).

Table 9. Suggestions on Uniforms

\begin{tabular}{lc}
\hline Focal points & $\mathbf{n}$ \\
\hline Sportive and comfortable & 131 \\
Made of fireproof fabric & 22 \\
Total & $\mathbf{1 5 3}$ \\
\hline
\end{tabular}

It is shown in Table 7 that total 155 participants offered suggestions about police. The majority these participants $(n=131)$ suggested that uniforms should be sportive and comfortable. Views and suggestions of a participant about this matter are as follows:

Policing requires constant movement. Being restricted by uniforms, especially, while tagging the suspect is not acceptable. Generally, our uniforms are suitable for office services; they are not convenient with using actively in the field; sportive official uniforms and choosing shoes accordingly (comfortable summer shoes instead of cowbide leather) will both make our foot patrolling colleagues comfortable and not cause injuries duty falling during counteracting events.

22 participants indicated that they should be made of fireproof fabric because police officers sometimes involve in fire incidents or illegal groups throw Molotov cocktails to police officers.

Table 10. Police Vehicles

\begin{tabular}{lc}
\hline Focal Points & $\mathbf{n}$ \\
\hline Renewing existing vehicles & 76 \\
Having periodical maintenance of vehicles & 36 \\
Changing the tyres of vehicles in due time & 11 \\
Total & $\mathbf{1 2 3}$ \\
\hline
\end{tabular}

It is shown that total in Table 8 that 123 participants had suggestions about police vehicles. The most suggested subject by the participants $(n=76)$ is buying newer and safer cars by renewal of the existing vehicle. Criticism of a participant is interesting:

Police officers are always warned about the priority of life safety, but it is in vain. Because Mercedes brand vebicles of statesmen are escorted by Hyundai and Renault brand vehicles. Is this logical according to you? Can Hyundai reach the speed of Mercedes? What is the percentage of being saved alive out of Hyundai in case of an accident? 
Gözübenli, M., \& Harmanc1, F. M. (2016). An investigation of occupational accidents and safety risks in policing: Views of employees. International Journal of Human Sciences, 13(1), 809-829. doi:10.14687/ijhs.v13i1.3446

Some participants also suggested having periodical maintenance $(n=36)$ and changing tyres of vehicles in due time $(n=11)$. Views and suggestions of a participant about the importance of tyres are as follows:

The most remarkable factor leading our vehicles to make accident is tyres according to me. Personnel are trying to manage to work with worn and repaired tyres full of holes wherever I work. They fear to request. Lifetime of a tyre is apparent. Can it be possible to replace them at a certain period of time or kilometre by following up by the logistics?

Table 11. Suggestions on Physical Fitness and Health

\begin{tabular}{lr}
\hline Focal Points & $\mathbf{n}$ \\
\hline Making regular sport and exercise & 45 \\
Providing facilities for the personnel for doing sport & 25 \\
Performing health check of the personnel at certain intervals & 12 \\
Total & $\mathbf{9 9}$ \\
\hline
\end{tabular}

It is shown in Table 9 that total 99 police officers had suggestions about physical fitness and health of police officers. According to the majority of these participants $(n=45)$, police officers should protect their physical condition and health by doing sport and exercise regularly. It is also suggested by some participants $(n=25)$ that police departments should provide facilities like sport halls to enable the personnel do sport both during and out of duty hours. Suggestion of one of the participants who expressed that most of the personnel did not habit of doing sport is interesting:

Our police officers should be encouraged to do sport. Sport halls should be built in Police

Departments, underpolice stations and lodgings as in western countries, and they should benefit from sport facilities which are in abundant amount in the market for free of charge or cheaply through buying service.

Some of the participants $(n=12)$ expressed that the health of the personnel should be regularly checked and inadequate personnel should have undergo for necessary treatment.

\section{Discussion}

Opinions and suggestions of 1066 employees currently working at different ranks and units in Turkish National Police participated in this research. When demographical features of the participants are reviewed it is understood that personnel from every rank, province, age, unit, experience participated. The majority of the participants are male $(97,4 \%)$, police officers $(82 \%)$, have two-year degree or bachelor's degree. $(94,9 \%)$, work in operational units $(\% 71,1)$ and from western cities (76,2\%). The average is 37,6 and year of service is 14,5 . It is assessed that these demographical features reflect the general views of Turkish National Police.

The participants were asked whether they had occupational accident previously and 364 of them $(34 \%)$ said they previously had one or more. Of 353 participants, who stated that they had occupational accident, nearly $2 / 3$ of the participants $n=212$ ) who stated that they had occupational accident were either assaulted since the suspect resisted or physically (punching, pushing, kicking etc.), and $1 / 3$ of them were subject to completely situations that are assumed mere accidents like traffic accidents falling down, gun burst, electric shock, fire/explosion. These data show that the personnel of Turkish National Police are subject to more resistance or assault and get injured as different from other researches. Furthermore, cases like electric shock, fire/explosion and dog biting that are not often encountered in the literature are shown, even less in number. The fact that $1 / 3$ of the participants previously experienced occupational accident is 
Gözübenli, M., \& Harmanc1, F. M. (2016). An investigation of occupational accidents and safety risks in policing: Views of employees. International Journal of Human Sciences, 13(1), 809-829. doi:10.14687/ijhs.v13i1.3446

considered remarkable in respect to transfer their positive-negative experiences they obtained from them.

It is understood that any kind of unwanted occurrence happened to police officers while they perform their duty should be considered as occupational accident according to base on the perception of participants. This is also true when considering the mentioned definitions of occupational accident and basic factors of occupational accidents. Cases like involving in traffic accidents and misfiring arise from their own fault of police officers, and they are unwanted/unexpected incidents. On the other hand, being assaulted with a gun or attacked physically are outer coming, suddenly happening and unwanted/unexpected incidents. In developed countries, such incidents assessed as occupational accidents by official authorities, but not in Turkey.

Participants' suggestions in respect to prevent occupational accidents in policing evaluated in total nine themes consisting of training, physical fitness and health, security measures, institutional policies and procedures, managerial applications, working conditions, equipment, uniforms, and patrol vebicles. Results of this research match up with the measures to prevent occupational accidents occurring in the profession of policing in the literature in general meaning on a large scale. Leading subjects (focal points) in regard with these themes when suggestions of the participants are evaluated together with the relevant literature in this research are as follows.

\subsection{Training}

Training is one of the topics that the participants emphasized most. It is shown in the literature that many researchers (Fiedler, 2001; Mayhew, 2001) expressed that training is one of the most important factors to reduce occupational accidents and safety related risks in policing. It was found out that the police officers got less injured and died who took sufficient training on arresting, detaining, using force or firearm in the researches done in the U.S. (IACP, 2009). Fiedler (2011) expressed that injury of the police officers decreased and the amount of annual compensation paid to the police decreased to 1 million dollars from 3.5 million dollars $(70 \%)$ thanks to the training about arresting and detaining techniques provided in 34 police departments in line with a programme planned in the State of California, U.S.

It is understood that the participants emphasized on training about guns and shooting techniques most. Importance of training about guns and shooting techniques arises from the fact that gun is an irreplaceable equipment which any policeman does not leave all along his career. Almost any policeman may have to use the gun he carries with him one day. Therefore, training to be given about this subject plays a critical role to reduce probable accidents that may occur when gun is used and save the life of the staff. The second training that the participants suggested was about physical defence tactics. Many researchers (Fiedler, 2011; Kaminski \& Sorensen 1995; Mayhew, 2001) pointed out that the trainings on defence tactics are especially important during searching the suspect, arresting and detaining procedures, since most of the assaults against the police are physical like punching, pushing and kicking.

Some of the participants suggested that trainings should be given by qualified and expert trainers. Mayhew (2001) suggested that in-service courses should directly be related with the tasks of the police and repeated by updating from time to time. Flavin (1998) indicated that the fact that the instructors who give trainings to police officers were enlightened ensured the police officers to learn correct information and feel self-confidence, while Fiedler (2011) pointed out that tactical trainings developed the abilities of the police related with policing applications like driving, detaining, intervening with incidents of violence and firearm using.

\subsection{Physical fitness and health}

Some of the participants expressed that when the physical conditions of police officers are good, they are less likely involve in an accident or get injured easily. Therefore, police officers 
Gözübenli, M., \& Harmanc1, F. M. (2016). An investigation of occupational accidents and safety risks in policing: Views of employees. International Journal of Human Sciences, 13(1), 809-829. doi:10.14687/ijhs.v13i1.3446

should do exercise regularly and authorities should provide necessary facilities to enable them do sport as well. Significance and benefits of physical condition and health in policing were established in the literature (Pinizzotto vd., 2002; Boylen and Little, 1990; IACP, 2009). Some researchers indicated that police officers who do sport and exercise regularly would be prepared and resistant against all kinds of difficulties as well as have a healthy body (Anderson, Litzenberger \& Plecas, 2002; Fiedler, 2001; Kayıhan and Ersöz, 2010). Anderson et al. found that diseases like heart attack, ulcer, diabetes, sleep disorder were mostly seen in police officers whose physical condition and health were not good. According to official statistics held in the U.S., the police officers who were physically in good condition, normal weight and healthy, and who did sport regularly, got injured less and caused much less (0,5 day) loss of manpower compared to physically inadequate and overweighed ones (IACP, 2009). Quigley (2008) explained that when police officers were physically in good condition, they would less likely be sick, which in turn reduced health expenses. Feidler (2011) pointed out that police officers who do regular exercise are less likely to have stress and depression.

Some of the participants remarked that health of police officers should regularly be checked and the ones who need treatment should be treated immediately. Shell (2005) argues that health check of police officers are frequently done during their candidacy and at police school, but it is not often done after they start to work and it is not considered in performance evaluations. Quigley (2008) indicates that being in good condition and having a healthy body directly affects the task performance, since actions like climbing, jumping, lifting, pulling, force using during the duty of the police require some certain strength and power.

\subsection{Security measures}

One of the themes that the participants emphasized most is obeying the rules related with security while responding to incidents and suspects. Mayhew (2001) alleged that the fact that the police underestimate probable hazards and responding to incidents without taking necessary measures were the major factors in the incidents resulting in death of them. Pinizzotto, Davis and Miller (2000) pointed out that especially veteran police officers gained self-confidence as they respond to events; so they do not avoid taking risks. These officers are often rewarded by their supervisors because of their courage, but when the other police officers witnessing these try to prove their courage by ignoring the risks in responding to events cause unwanted results. Pinizzoto et al. (2000) argued that the police officers who had occupational accidents were known mostly hardworking and prone to take risk.

Some participants indicated that police officers should absolutely wear equipment like steel vest, helmet, and protective armour in critical and risky incidents. Many researchers expressed that steel vest is a very important equipment saving the life of police officers (Mayhew, 2001; Boylen \& Little, 1990). Research in the U.S. showed that death of police officers were generally caused by firearms (Boylen \& Little, 1990; Brown \& Langan, 2001; Mitchell, Stevenson \& Poole, 2000) and the police officers who did not wear steel vest were under the risk of dying due to firearms at much higher rate compared to the ones who wear steel vest (Knight 1999; Boylen \& Little, 1990). Fiedler states that 306 of the police officers out of 521, who were killed between 1997-2001 in the U.S., did not wear steel vest (PERF, 2011). Builta and Ward (1995), on the other hand, emphasized that gradual increase in the rate of carrying gun illegally increased the significance of steel vest.

\subsection{Institutional policies and procedures}

The participants mentioned the importance of institutional policies in the prevention of occupational accidents. Many participants mentioned that the current procedures were not sufficient to prevent occupational accidents and police officers responded wrong in many incidents in hesitation. They mentioned that in this respect, confusion that may arise in police officers should be removed by preparing detailed and net procedures especially for every risky 
Gözübenli, M., \& Harmanc1, F. M. (2016). An investigation of occupational accidents and safety risks in policing: Views of employees. International Journal of Human Sciences, 13(1), 809-829. doi:10.14687/ijhs.v13i1.3446

task. Standard operation procedures (SOP) were developed in police departments of many developed countries especially in the U.S. and the U.K. for police applications like foot and vehicle pursuits, critical operations, building and hostage operations, arresting, detaining, suspect carrying techniques and firearm using (Fiedler, 2011). Furthermore, occupational health and safety policies and strategies were developed and a separate unit under the same name was founded to reduce occupational accidents and safety related risks in policing in police departments in developed countries (Mayhew, 2001). This unit prepares standard operation procedures, makes amendments according to changing conditions, controls whether these procedures are obeyed or not and organizes programmes about training of police officers by analysing risks related with the tasks of police officers (Pinizzoto et al., 2002). Police officers know how to behave in which situations clearly thanks to these programmes (Pinizzoto et al., 2002). Although occupational health and safety office was founded in Turkish National Police in 2014, this office is not functional and it does not have authority to audit. It is understood that most of the staff does not know about this unit when the statements of the participants are reviewed.

\subsection{Managerial applications}

The participants expressed that police managers play an important role in the prevention of occupational accidents, and thus, they should personally lead their staff in especially critical and risky incidents, warn them about safety measures like wearing steel vest etc. and not endanger them in risky situations. According to the participants, duty of police managers is to show the mistake if one acted wrong, and train, guide and audit them. Fiedler (2011) pointed out that rates of accident would decrease if police managers regularly check whether police equipment is full, firearms are properly stored, protective vest and helmets are worn, and the officers act according to instructions and procedures. Mayhew (2001) emphasized that existence and observation of police managers in crime scene in high risk cases like armed robbery, narcotics operations or responding to lunatics is vital.

The participants also suggested that chiefs should check the psychology of the personnel as well as obeying the rules. Fiedler (2011) alleged that posttraumatic stress disorder or depression were mostly seen in police officers who especially intense and distressful environments or experienced a traumatic incident (bomb explosion I the crime scene etc.). According to Fiedler, these officers were more inclined to suicide. Violanti (1996) proposed that police managers should give risky tasks those officers having stress and depression. Vila, Morrison and Kenney (2002) indicated that depressed, tired, sick and weak personnel would jeopardize not only their own life, but also other team colleagues and citizens; thus, police chiefs should check if the staffs are suitable for the risky tasks. In his report called "Recommendation" dated 30.12.2014, Turkish Public Chief Auditor Nihat Ömeroğlu, pointed out those police officers get exhausted socially, emotionally and culturally compared to other professionals. According to Ömeroğlu, police managers should enable psychological support and guidance services to police officers more efficiently.

\subsection{Working conditions}

According to the participants, heavy working conditions cause carelessness and tiredness which cause making mistakes and accidents. Research has shown that heavy working conditions in policing had negative effects like tiredness, exhaustion and weakness (Vila, 1996; Vila et al., 2002). Vila, (1996) found that police officers who worked when tired were more likely involve in accidents. In a study by Vila et al., (2002), on the other hand, it was found that sleep quality of police officers were twice as much less than general average of people. This study also revealed that when officers slept less, their level of stress increased, they were in difficulty to control their feelings, their performance decreased, and they lost their ability to decide in sudden cases. 
Gözübenli, M., \& Harmanc1, F. M. (2016). An investigation of occupational accidents and safety risks in policing: Views of employees. International Journal of Human Sciences, 13(1), 809-829. doi:10.14687/ijhs.v13i1.3446

Violanti (1996) pointed out that police managers should give short sleep pauses to their personnel and make them rest.

According to the participants, working conditions of personnel should be improved, extra and additional work decreased and they should be given enough resting time. Research has shown that situations like continuously changing shift system, additional tasks, obligation of frequently going to the court after duty make officers exhausted (Vila et al., 2002; Neylan et al., 2002). Studies show that the most suitable period of working time for human physiology daily maximum 7,5 hours and weekly 45 hours (Camkurt, 2007). Vila (1996) suggests that in order to prevent accidents in policing, police officers should not work more than 8 hours. Similarly, Nihat Ömeroğlu, Public Chief Auditor, indicated that working more than 8 hours a day and 40 hours a week and assigning for additional tasks. could cause physiological, psychological and sociological problems in respect to productivity, efficiency, feasibility, endurability, satisfaction, and performance. Ergonomical shift model was begun in some units of 33 Provincial Directorates of Security by year 2014, and police officers worked 8 hours a day and 40 hours a week, and it was understood that positive feedbacks were received from the police officers where this model was applied. But many Provincial Directorates of Security gave up this model and accepted the traditional model (12 hours work and 24 hours rest) within the last 1 year.

\subsection{Equipment}

The participants mentioned the deficiencies about equipment and suggested that all the equipment needed by personnel should be given to them fully and in good condition. Tear gas and light steel vest are the most emphasized equipment. Tear gas is one of the most important equipment to make suspicious persons who behave aggressively ineffective in many developed countries as well as in our country. Aschroft, Daniels and Hart (2001) pointed out that in a department where tear gas was begun to use injury of police officers decreased by $33 \%$. In regards to steel vest, it was accepted that usage of steel vest was the most important factor to enable police officers to survive (Mayhew, 2001; Boylen \& Little, 1990). Boylen and Little (1990) mentioned that today steel vests are produced lighter, more comfortable and practical and thus, they should be distributed to all officers as much as possible.

Many participants also suggested the use of electroshock weapon, which is considered as a nonfatal weapon. It was found out that using tear gas or electroshock weapon instead of direct contact with the suspect decreased injury of police officers at a meaningful level in a research made by Smith et al. (2009). Electroshock weapon is used in more than 15.500 police departments in more than 40 countries to make the aggressive ineffective (PERF, 2011).

\subsection{Uniforms}

The participants suggested that police uniform should be sportive, comfortable and nonrestricting the ability to move. Tenzel, Storms and Sweetwood (1976, p. 29-30) found that assaults against the police decreased by $30 \%$ after the alteration made in their uniforms. In a study by Kansoy, Dirgar and Kirtay (2008), it was found that clothes played an role to increase the efficiency of the work.

Another suggestion of the participants is the usage of fireproof fabric for uniforms. The fact that the police may be subject to assault with Molotov cocktails riots and under risk in respond to the fire increase the significance of the uniforms resistant to fire.

Furthermore, it was understood that the colour of the uniforms that police officers wear in road checks decreased traffic accidents. Harmanc1 and Doğan (2014) pointed out that a police officer in blue uniforms is noticed from 17 meters of distance, while policeman wearing a reflector uniform is noticed from 152 meters. 
Gözübenli, M., \& Harmanc1, F. M. (2016). An investigation of occupational accidents and safety risks in policing: Views of employees. International Journal of Human Sciences, 13(1), 809-829. doi:10.14687/ijhs.v13i1.3446

\subsection{Police vehicles}

The participants expressed that traffic accidents would decrease if police vehicles were safer and newer, their tyres were changed in due time and their periodical maintenance were done. It was found in a research about the analysis of traffic accidents in Turkey made by Sungur, Akdur and Piyal (2014, p. 118) that faults of vehicles leading to accidents caused by blowout by $58,8 \%$. Faulty brakes and steering rods were also found as remarkable factors in the same study. This finding is consistent with the suggestions of the participants about renewal of police vehicles and Fiedler's (2011) view that police chiefs should often check police vehicles.

According to Turkish Occupational Health and Safety Legislation operators and carriers who are directly or indirectly involved in the operation of motor vehicles have responsibility in technical fault, and there is no blowing off due to technical fault. Problems like coming out of steering rod, brake fade, blowout, and wheel nut cutting, steering wheel locking are considered within the scope of technical fault (Akman \& Issler, 2012). Therefore, issues of periodical maintenance of police vehicles, renewal of tyres in due time or renewal of vehicles will be useful regarding for not being subject to penal responsibility as well as positive effect on the occupational health and safety of the personnel.

\section{Conclusion and Recommendations}

This study investigates the views and suggestions of the personnel of Turkish National Police (TNP) to prevent occupational accidents and safety risks in policing. Police officers perform vital tasks in regard with establishing internal security, public authority, order and public peace, protection of personal rights and freedom of citizens. In this respect, policing means a different status from all other professions for every individual in the society; therefore, a good policing service should be rendered to continue every second of our daily life in security and peace. Enabling the personnel to render healthy service and providing safety for them should be among the most important priorities of decision makers in policing.

Research in the U.S. and U.K., have established that giving training to police officers, obeying safety rules completely by wearing equipment like steel vest, and leading subordinates closely in high risk situations and improving procedures (Boylen \& Little, 1990; Brown \& Langan, 2001; Builta \& Ward 1995; Fiedler, 2011; Kaminski \& Sorensen, 1995; Mayhew, 2001 Quinet, Bordua \& Lassiter, 1997). This study have revealed that according to opinions and suggestions of personnel of TNP, nine themes were emerged to prevent occupational and safety risks in TNP: 1) Training on occupation accidents and safety risks should be given to all police officers. 2) Police officers should for regular exercises and sport in order to be physical fit and healthy for challenging tasks. 3) Police officers should obey all the necessary security rules and measures. 4) Institutional policies and procedures should be renewed and ambiguities are eliminated. 5) Police managers should closely monitor and led their subordinates especially in risky situations. 6) Working conditions of police officers should be improved. 7) All necessary equipment in good condition should be given to police officers. 8) Uniforms must be changed and be comfortable and sportive, as well as fire proof 9) Police vehicles should be renewed and they are regularly checked.

Based on these suggestions, various inferences towards senior staff and decision makers in TNP (Directorate General of Public Security, Deputy General Directors, Provincial Police Chief and related officials of Chairmanship of Departments) can be drawn.

First of all, taking preventive measures is more important than all the efforts after occupational accidents occur. For this purpose, Occupational Health and Safety Unit, which was established within police departments, should be activated. Staff in this unit should find out probable problems that may be experienced in regard with security by carrying out analysis 
separately in terms of each unit (patrol, narcotics, terror, riot police etc.) and buildings of security (directorate of security, police centre building etc.). What equipment (steel vest, helmet, protective armour, gloves etc.) the staff need should be indicated while risk analysis is being done. Statistical analysis of the incidents occurred in the past should be done for risk analysis by collaborating with universities or occupational health and safety experts who work for different organizations if needed. Risk analysis should be prepared in a way to enable the personnel to work in a safer environment. How personnel should act in what situation should be clearly pointed out by preparing standard operation procedures in line with the risk analysis like in the western countries. This unit should also find out deficiencies about training and about which personnel should take which training, and these trainings should be provided by coordinating with Branch Directorates of Training. It should be cared that applied trainings should be given in line with scenarios adapted from real life, and since occupational accidents occur mainly because of careless actions, it should be emphasized.

Decision makers are also liable to provide the staff with the equipment (light steel vest, helmet etc.) they need fully and renewal of worn out equipment. Procurement of faster and safer vehicles would decrease traffic accidents and the rates of injury and death if happen. Besides this, all the advantages of the technology should be taken. For example, it is possible to decrease the fatigue of the personnel who stand guard for a long time by building bulletproof cabins, using wires for environment security, building protected sections in the entrance of police centres and using cameras for environment security. In addition, policies and procedures on use of force or firearms should be prepared in a way that everyone can understand in a single procedure, and the method of respond should be determined according to the level of risk, and all the practises should be implemented in accordance with these procedures. Furthermore, if uniforms are designed in a more comfortable and sportive way police officers would have more ability to move. For example, the uniform that the riot police currently use can be given to all other personnel.

Even though training programs, buying new vehicles and equipment, changing uniforms, conducting regular health checks require certain amount of cost, spending for these expenses should not be avoided. Providing training about physical defence tactics and firearm tactics etc. to the personnel, materials like light steel vest, tear spray, stick, and hand lamp and electro shock device, small hand wireless and buying safer vehicles should not be considered as luxury, but on the contrary as requirement. When loss of manpower and health expenses arising from loss of life and injury or being permanently disabled of the personnel are taken into account, it is assessed that the expenditure for training and equipment would worth it, and even less costly.

\section{Limitation}

This study offer some useful insights on occupational accidents and safety risk in policing, as well as security areas such as gendarmerie, special security etc. However, this study also has limitation. This study could not provide the statistics of occupational accidents occurred in Turkish National Police because of some institutional drawbacks. Subsequent studies should try to obtain and investigate how many occupational accidents (traffic accident, assault, resistance, falling etc.) occurred in TNP, how many of police officers involved in these accidents, how many of them lost their life, got injured, became permanently disabled, got sick leave, due to these occupational accidents, and which type of incidents (public order, social, narcotics etc.) were these which resulted in injury or death of the personnel, and ways of injury (physical, with stone, stick etc.), and demographical features of the injured/killed (age, gender, professional experience, unit/province of work etc.) in detail. These data will also enlighten the risk analyses to be prepared and ensure healthier measures to be taken. 
Gözübenli, M., \& Harmanc1, F. M. (2016). An investigation of occupational accidents and safety risks in policing: Views of employees. International Journal of Human Sciences, 13(1), 809-829. doi:10.14687/ijhs.v13i1.3446

\section{References}

Akman, A., \& İşler, M. C. (2012). Trafik iş kazalarının iş sağlı̆̆1 ve güvenliği mevzuatı açısından değerlendirilmesi. International Journal of Engineering, 4(2), 21-25.

Allard, T., \& Prenzler, T. (2009). A summary analysis of police deaths in Australia: Implications for prevention. International Journal of Comparative and Applied Criminal Justice, 33(1), 61-81.

Anderson, G. S., Litzenberger, R., \& Plecas, D. (2002). Physical evidence of police officer stress. Policing: An International Journal of Police Strategies and Management, 25(2), 399-420.

Ashcroft, J., Daniels, D. J. \&Hart, S. V. (2001).The Effectiveness and Safety of Pepper Spray. U.S. Department of Justice Office of Justice Programs National Institute of Justice, https://www.ncjrs.gov/pdffiles1/nij/195739.pdf

Balc1, A. (2007). Sosyal Bilimlerde Arasttrma. Ankara: PEGEM Yayımları.

Bostanc1, Y (2005). Yargitay Kararlar Iş⿳亠口冖ında Iss Kazası Kavramı. Kamu- $\dot{I}_{s}$, 8(1), http://www.kamuis.org.tr/pdf/813.pdf.

Boylen, M., \& Little, R. (1990). Fatal assaults on United States law enforcement officers. Police Journal, 63(1), 61-77.

Brandl, S. G., \& Stroshine, M. S. (2012). The physical hazards of police work revisited. Police Quarterly, 15(3), 262-282.

Brown, J. M., \& Langan, P. A. (2001). Policing and homicide, 1976-98: Justifiable homicide by police, police officers murdered by felons. US Department of Justice, Office of Justice Programs, Bureau of Justice Statistics.

Brown, J. M., \& Langan, P. A. (2001). Policing and homicide, 1976-98: Justifiable homicide by police, police officers murdered by felons. US Department of Justice, Office of Justice Programs, Bureau of Justice Statistics.

Builta, J., \& Ward, D. (1995). Attacks on police officers in the US. CJ the Americas, 8(2), 13-14.

Çam, İ. (1991). Türkiye'deki iş kazaları ve meslek hastalıkları probleminin çözümünde iş güvenliği eğitiminin önemi üzerine bir araştırma. MPM Verimlilik Dergisi, 20, 4-23.

Camkurt, M. Z. (2007). İşyeri çalışma sistemi ve işyeri fiziksel faktörlerinin iş kazaları üzerindeki etkisi. TÜHİ Iss Hukuku ve İktisat Dergisi, 20(6), 80-106.

Camkurt, M. Z. (2013). Çalışanların Kişisel Özelliklerinin İş Kazalarının Meydana Gelmesi Üzerindeki Etkisi. TÜHİS İs Hukuku ve İktisat Dergisi, 24(6), 70-101.

Driscoll, T., Mitchell, R., Mandryk, J., Healey, S., \& Hendrie, L. (1999). Work-related traumatic fatalities in Australia, 1989 to 1992. Canberra: NOHSC, AusInfo.

Fiedler, M. L. (2011). Officer Safety and Wellness: An Overview of the Issues. COPS, http:// cops.usdoj.gov/pdf/OSWG/e091120401-OSWGReport.pdf

Flavin, Jeanne. (1998). Police and HIV/AIDS: The risk, the reality, the response. American Journal of Criminal Justice 23(1), 33-58.

Güzel, A., Okur, A. R., Caniklioğlu, N. (2012). Sosyal Güvenlik Hukuku.(14.Bası).İstanbul: Beta Yayinlar1.

Hackitt, J., Podger, G., Fahy, P., \& Orde, H. (2009). Striking the balance between operational and health and safety duties in the Police Service, http://www.hse.gov.uk/services/police/duties.pdf

Harmanc1, F. M., \& Doğan, A. S. (2014).İ̧s Kazaları ve İşyerinde Sağlık Sorunları. M. Harmanc1, M. Gözübenli, \& M. Dağlar (Ed) içinde, Güvenlik Sektöründe Taktiksek Yöneticilik. Ankara: GÜSAM-Nobel Yayınevi.

ILO (1983).Encyclopaedia of occupational safety and health. Geneva. 

Views of employees. International Journal of Human Sciences, 13(1), 809-829. doi:10.14687/ijhs.v13i1.3446

Kaminski, R. J., \& Sorensen, D. W. (1995). A multivariate analysis of individual, situational and environmental factors associated with police assault injuries. American Journal of Police, 14(3/4), 3-48.

Kaminski, Robert J. 2007. Police foot pursuits and officer safety. Law Enforcement Executive Forum, 7(3), 59-72.

Kansoy, O., Dirgar, E., \& Kırtay, E. (2008). Sanayide Çalışanlar İçin Uygun İş Kıyafetlerinin Geliştirilmesi. Tekstil ve Konfeksiyon, (4), 306-310.

Kayıhan, G., \& Ersöz, G. (2010). Assessment of Ankara Police College students' body composition. International Journal of Human Sciences, 7(1), 97-113.

Knight, A. (1999).In the line of duty: 1999 survivors' club anniversary update. The Police Chief, 66(5), 45-51.

Mayhew, C. (2001). Occupational Health and Safety Risks Faced by Police Officers. Australian Institute of Criminology, Trends \& issues in crime and criminal justice. http://www.aic.gov.au/media_library/publications/tandi_pdf/tandi196.pdf

Mitchell, M., Stevenson, K. S. \& Poole, D. (2000). Managing Post-Incident Reactions in the Police Service, Research Report no. R54.069, Health and Safety Executive, London. http://www.hse.gov.uk/research/crr_pdf/2000/crr00290.pdf

National Law Enforcement Officers Memorial Fund( 2015). Latest Memorial Fund Fatalities Report, http://www.nleomf.org

Neylan, T. C., Metzler, T. J., Best, S. R., Weiss, D. S., Fagan, J. A., Liberman, A., ... \& Marmar, C. R. (2002). Critical incident exposure and sleep quality in police officers. Psychosomatic Medicine, 64(2), 345-352.

Ömeroğlu, N. (2014). Kamu Deneţiliği Kurumu (Ombudsmanlı) Tavsiye Karar. Şikâyet No : 2013/171 Karar Tarihi : 30/12/2014. http://www.ombudsman.gov.tr/contents/files/PolislerinhaklarındüzeltilmesiTalebiKarar

PERF (Police Executives Research Forum). Electronic control weapon guidelines. http://www.policeforum.org/assets/docs/Free_Online_Documents/Use_of_Force/elec tronic $\% 20$ control $\% 20$ weapon $\% 20$ guidelines $\% 202011$.pdf

Pinizzotto, A. J., Davis, E. F., \& Miller, C. (2002). Accidentally dead: Accidental line-of-duty deaths of law enforcement officers. FBI Law Enforcement Bulletin, 71(7), 8-13.

Pinizzotto, A. J., Davis, E. F., Miller, C. E., Hitt, S. L., Scholle, A. D., \& Crawford, K. A. (2000). Officers' perceptual shorthand. FBI Law Enforcement Bulletin, 69(7), 1-11.

Prenzler, T. (2006). Towards prevention: A situational study of police deaths on duty in Queensland. Current Issues Criminal Justice, 18 (1), http://www98.griffith.edu.au/dspace/bitstream/handle/10072/13681/39782_1.pdf?seq uence $=1$

Quigley, A. (2008). Fit for duty? The need for physical fitness programs for law enforcement officers. Police Chief, 75(6), 62.

Quinet, K. D., Bordua, D. J., \& Lassiter III, W. (1997). Line of duty police deaths: A paradoxical trend in felonious homicides in the United States. Policing and Society: An International Journal, 6(4), 283-296.

Savery, L. K., Soutar, G. N., \& Weaver, J. R. (1993). Stress and the police officer: Some West Australian evidence. Police Journal, 66(3), 277-290.

Shell, D. E. (2005). Physical fitness: Tips for the law enforcement executive. FBI Law Enforcement Bulletin, 74(5), 27-31.

Shucard, J. L., Cox, J., Shucard, D. W., Fetter, H., Chung, C., Ramasamy, D., \& Violanti, J. (2012). Symptoms of posttraumatic stress disorder and exposure to traumatic stressors 
are related to brain structural volumes and behavioural measures of affective stimulus processing in police officers. Psychiatry Research: Neuroimaging, 204(1), 25-31.

Smith, M., Kaminski G., Alpert, L., Fridell, J., Macdonald, J., \&Kubu, B. (2009). A multi-method evaluation of police use of force outcomes. Washington, D.C.: National Institute of Justice.

Sungur, İ., Akdur, R., \& Piyal, B. (2014).Türkiye'deki Trafik Kazalarının Analizi. Ankara Medical Journal, 14(3), 114-124.

Tenzel, J. H., Storms, L., \& Sweetwood, H. (1976). Symbols and behaviour-experiment in altering police role. Journal of Police Science and Administration, 4(1), 21-27.

The IACP Center For Officer Safety \& Wellness. (2009). A Summary of Data Findings and Recommendations from a Multi-Agency Injury Tracking Study, http://www.theiacp.org/portals/0/pdfs/IACP_ROI_Final_Report.pdf

Türen, U., \& Gökmen, Y. (2014).Türkiye'de meydana gelen iş kazaları sonucu ölümler ile çalışanların yaş faktörü arasındaki ilişki. Sosyal Güvenlik Dergisi, 4(1), 101-119.

Vila, B. (1996). Tired cops: Probable connections between fatigue and the performance, health and safety of patrol officers. American Journal of Police, 15(2), 51-92.

Vila, B. J., \& Kenney, D. J. (2002). Tired Cops: The Prevalence and Potential Consequences of Police Fatigue. National Institute of Justice Journal ,248, 16-21, www.ncjrs.gov/pdffiles1/jr000248d.pdf

Vila, B., Morrison, G. B., \& Kenney, D. J. (2002). Improving shift schedule and work-hour policies and practices to increase police officer performance, health, and safety. Police Quarterly, 5(1), 4-24.

Violanti, J. M. (1996). Residuals of occupational trauma: Separation from police duty. In D. Paton \& J. M. Violanti, Traumatic stress in critical occupations: Recognition, consequences and treatment (pp. 113-138). Springfield, IL, England: Charles C. Thomas.

Wolcott, H. F. (1994). Transforming Qualitative Data: Description, Analysis and Interpretation. Newbury Park, CA: Sage.

Yıldırım, A., \& Şimşek, H. (2006). Sosyal Bilimlerde Nitel Araştırma Yöntemleri. (6. Baskı). Ankara: Seçkin Yayınları.

Yılmaz, Ş. (2013). 6331 Sayılı İş Sağllğı ve Güvenliği Kanunu'nda Önleyici Yaklaşım ve İşverenlerin Yükümlülükleri. TÜHIS İs Hukuku ve İktisat Dergisi, 24, 44-69. 